\title{
Enlightenment of Confucian Music Education on Improving College Students' Humanities Accomplishment*
}

\author{
Qin Zeng \\ College of Fine Arts and Film \\ Chengdu University \\ Chengdu, China 610106
}

\author{
Mengni Fan \\ College of Fine Arts and Film \\ Chengdu University \\ Chengdu, China 610106
}

\begin{abstract}
This paper has studied the thought of Confucian music culture of Confucius, Mencius and Xunzi. Also, it has explored the connotation of Confucian music culture. And contemporary college students would study and understand the essence of Confucian music culture. The contemporary college students would improve their own humanities, and cultivate both ability and political integrity.
\end{abstract}

Keywords-Confucianism; the culture of music education; humanity accomplishment; enlightenment

\section{INTRODUCTION}

Confucianism is the traditional Chinese culture represented by Confucius, Mencius and Xunzi in the Spring and Autumn Period and the Warring States Period. Confucian music culture is an important part of Confucianism, among which "music education" is famous. Confucian sages believed that "music" was an important part of personal qualities and an important condition for cultivating complete personality. Confucius ever said that we could cultivate the personality with the study of poetry, ritual and music learning." In the Confucian music education culture, "rites" and "music" complement each other. And "rite" is a code of conducts and norms. "Music" refers to the music education. Confucian music education regulates people's thoughts and behaviors. With the rhythm, it could educate people to practice the ritual system. Then, it could ensure the stability of society. The idea of music education gives rise to the sense of cognition and sense of consciousness. It would stimulate people's positive feelings of loving life and experiencing life, sway people's conduct and improve people's character.

In China, the university campus is an important base for personnel training. The overall quality training for college students is accomplished mainly through moral, intellectual, physical and aesthetic aspects. The idea of Confucian music education has influenced Chinese education with its unique

*Fund Project: This article is phased achievements of "Research on the educational function of Confucian music culture to college students from multicultural perspective" of "Key Research Base of Philosophy and Social Sciences in Sichuan Province" and "Key Research Base of Humanities and Social Sciences in Colleges and Universities of Sichuan Province" in 2017. (Project No. DYWH1709) charisma. And it has made guidance and inspiration on the cultivation and improvement of the humanistic accomplishment of college students.

\section{CONFucius Thought OF Music EduCATION AND ITS ENLIGHTENMENT ON THE QUALITY-ORIENTED EDUCATION OF COLLEGE STUDENTS}

Confucius was the founder of Confucianism. He proposed the education idea of "six arts", namely, rites, music, shooting, driving, books and numbers. In the later years, he revised the six classics, namely "The Book of Songs", "The Book of History", "The Rites", "Classic of Music" and "The Spring and Autumn Annals". And he used the six classics as the textbook. He required the students to learn the text and make self-discipline with the rites". That is to say, the students should learn a wide range of cultural knowledge, and use the rites to restrain themselves. The socalled "culture" actually includes music. Therefore, it can be seen that the generalized culture said by Confucius including music must be constrained by the rule of civilization - "The Rites". Since ancient times, Chinese culture has always regarded "The Rites" and "Classic of Music" as "rites and music culture". Therefore, there are complementary and inseparable relations between "the rites" and "music". Confucius paid special attention to "the rites" and "music", which opened the precedent of Confucian ritual and music education in pre-Qin dynasty. In the process of cultivation and education, "music education" occupies a very important position in Confucius's educational thought. Confucius regarded "music education" as the highest level of personality. This also shows that the idea of rites and music education is an important part of Confucian musical culture.

Confucius not only valued music in his achievements, but also integrated music into his education. As for the Confucian deeds of "poetry, books, rites, music and education", there is a clear record in "The Historical Records - Confucius". And Confucius required the students to master the six basic qualities of "rites, music, shooting, driving, books and numbers". In his own teaching activities, Confucius made extensive use of music to enlighten his disciples and used his ritual poems to wash the hearts of his disciples. It enhanced their personality and virtue in an all- 
round way. In "The Rites of Zhou - Bao", it said that we could taught the prince with the six arts of Confucianism. The first was five ceremonies. The second was six arts. The third was five shooting. The fourth was five driving. The fifth was six books. The sixth was nine numbers. Therefore, to master the Five Classics and Six Arts is basic accomplishment of the students in Zhou Dynasty. And "music" refers to the music training.

In the Confucian cultural system headed by Confucius, "benevolence" is one of the highest moral qualities of a person and is the core concept of Confucianism. In Confucius' great expositions on "benevolence", "benevolence" refers both inward and outward culture. Confucius restrained himself with "benevolence" to be selfcultivation. It is a kind of courage to restrain oneself and become a man. It is also courageous "righteousness and quality." He believed that it was necessary to achieve the goal of "benevolence" and "righteousness." And a gentleman should constrain themselves with certain standard and etiquette. Confucius insisted on "benevolence" to the outside world. That is, we should treat people with the rites. The "first filial piety, second confidence" in "Three Character Classic" is a very good interpretation of the "rites" proposed by Confucius. Confucius advocated the rites of Zhou and looked forward to rebuilding the order of society of the Zhou rituals. That is to "keep the order, and to be humbled". "There is a difference in respect for each other." He said that disciples would have filial piety at home. And these disciples should love and respect one's elder brother outside. Also, they should be cautious and reliable. And these disciples should love other people and be beneficent. In addition, these disciples could learn to be a man. Also, these disciplines could spare no effort to learn cultural knowledge. Confucius required students to honor their parents at home, and respect their elders outside. This is the basis for college students to behave in society. At present, most of the undergraduates are only children. With much attention from the society, affectionate love from their parents, it lacks the order between teachers and students. And the teachers would loss stateliness. The students would loss the morality of respecting teachers. And even, the students would insult teachers or fights with the teachers. At the same time, it also led to the social ills of "moonlight clan" and "boomerang kids". We have to pay attention to these phenomena. University students need to understand and study the sage's philosophical thoughts, enhance their own humanistic accomplishments. And then, they wouldn't become a person with high-level intelligence and low quality and poor personalities.

\section{Mencius's Thought OF Music EdUCATION AND ITS ENLIGHTENMENT ON QUALITY EDUCATION OF COLLEGE STUDENTS}

On the basis of Confucius theory of human nature, the Second Sage Mencius proposed the theory of "goodness", inherited Confucius' idea of music education and brought it to a new height.

First, it is the concept of music education. Mencius inherited the ideological foundation of "benevolence" taught by Confucius. Mencius believed that people had the moral nature of "benevolence, righteousness, rites and wisdom". He said that righteousness would make me happy, and the meat would make me have good taste. (Mencius-the first part of gaozi) He believed that "Truth" as a social ethics, which is the understanding of society at the time. From the perspective of the morality, "righteousness" is a norm, an evaluation, or even an ideal. The sound, rhythm and tone of music teaching are expressed through the senses, and would bring happiness for the people. In the music education, people could get happiness and satisfaction. Also, the music would give people encouragement and joy. And people would dance with the music. From this perspective, the cultivation of college students' humanistic accomplishment can be realized through music education. The college students would express their own heart through music. And the music could make them feel happy, passionate and positive.

Second, it is the moral education of music. Mencius put forward the theory of "goodness," believing that everyone had the basic morality of "goodness". Mencius made a clear positioning of the category of "music education". With "benevolence" as the center, Mencius made the aesthetic education. He also required the moral quality of the students. In his opinion, all the people must firstly comprehend "benevolence" from "music". And people could perfect character with the "benevolence" of the music. And then, people would achieve the goal of "goodness" through the sublimation of morality. Therefore, the idea of "music" can improve human character. Also, it could improve the nature of people, and achieve moral norms in society and at home. Therefore, Mencius put forward moral requirements for the musicians. In choosing the content of "music," Mencius asked to have "benevolence" as the core. And the elegant content should be the basis. In order to integrate the formal beauty and emotion, the "music" must be expressed through the morality of the humanity. Only in this way can people express their noble thoughts and feelings when they enjoy "music" and experience the feelings of "music". "Music education, kindheartedness, and beauty" are the development of "music education" of Mencius. And they are also the understanding of the essence of "music education." Mencius valued the relationship between "music" and morality. He realized that "music" had a function of exciting and touching people. And "benevolence" as the most fundamental purpose of "music" has a strong role of enlightening the society. In "Mencius - Gongsun Chou", if someone had no sense of shame, he wouldn't be a man. People can't be shameless. People would be shameless without the sense of shame. Those who do not have "sense of shame" can't be counted as human beings. And these people wouldn't feel ashamed or disgusted with their own mistakes or shameful things of others.

At present, most of the college students are only children. Various factors lead to the sub-health of body and mind, early-maturing physiology and late-maturing mind. The college students lack the experience to understand the world. They would face various temptations and pitfalls. With the dramatic changes in recent years both at home and abroad, 
and the influences of market economic values, the morality and values of college students are in the state of chaos. Money worship, hedonism and extreme individualism are ubiquitous among college students. It has a series of "embarrassment and shame" in institutions of higher education. For example, a female college student of the generation after 1990s in Fuzhou flaunted the considerable wealth. They sell their body to buy "luxury gold color" phone. There even was "nude loan" of a female college student. This female college student can't repay the high interest rates repayments. In the end, the lenders spread out personal nudity of this college student. Then, she even committed suicide. Therefore, in the new social situation, the universities and colleges should encourage the college students to establish correct values and form the correct concept of interests. And it is a new demand for higher education in China. The Confucianism and Taoism have farreaching significance for college students to establish correct humanistic values and improve their humanistic accomplishments.

\section{ENLIGHTENMENT OF XUNZI's ThOUGHT OF MusiC EduCATION ON CULTIVATION OF COLLEGE STUDENTS' HUMANISTIC ACCOMPLISHMENTS}

Xuncius is a master of pre-Qin Confucianism and an outstanding educator, who was revered as "Xun Qing." Following Mencius, Xuncius also put forward the theory of "doctrine of evil human nature" in the aspect of humanity. Contrary to Mencius's theory of "doctrine of good human nature", Xuncius believed that human nature was evil. And he thought that human would betray natural moral values. And Xuncius emphasized the environment and the influence of education on people .

Confucianism's idea of music education of Xunzi is based on "doctrine of evil human nature", which can be found in Xunzi's "music theory" and other chapters on "music education." In "evil human nature", any sense of righteousness was born in the pseudo saint, and it is not born in the human nature. Xunzi believed that human morality was not inherent, and human nature was given by God. If we don't control the morality and develop this nature of human beings at will, there would be a formation of evil. If we want to change this kind of unhealthy moral behavior, we should control it by means of "the rites and morality". And then, we would cultivate moral character. Xunzi's idea of music education is reflected in the following aspects.

First, in terms of the cultivation of music education, Xunzi believed that music education occupied a very important position in the spiritual world of people, and music education was essential. The human nature could be divided into good and evil. If we don't control the "the rites and morality" and develop the music at will, the society would have the riot. And people would have no peace. In order to prevent riots and facilitate the management of society, the kings often use the "Odes and Hymns" to make influence on the kindness. This kind of "Odes and Hymns" is based on the idea of "kindheartedness". It prevents the development of the human nature from evil in bad social atmosphere. And then, we could achieve the purpose of cultivating human sentiments and fulfilling the request of the kings. The enlightening role of "music" can be exerted in society. The music education has enlightenment on the formation and transformation of the mindset of human brain and the cultivation of human character. It plays an important role in the transformation of human moral character and social ethos. "The saint likes the music, and it can be used to bring peace to the people. We could change the old customs. The first king would guide people with the ritual. And people would be in harmony. Therefore, the idea of using "music" to improve human nature and the social ethos has been highly valued since ancient times. "Music" enables people to help each other, to unite and cooperate, and to make the community be stable. This is the so-called the role of music education in the cultivation of personality. We can see that Xunzi attaches great importance to the distinction between the goodness and evil. "Goodness and evil" are embodied in the content and form of the "music". Therefore, the wonderful and noble "music" can correct people's conduct and improve people's accomplishments. It would achieve the goal of enlightening the people and the stability and unity of the society. This could embody the core of Xunzi's music education philosophy.

Second, in terms of aesthetic teaching of music education, Xunzi believed that "music" could bring peace of mind for the individual.

For China, "music" could lead to peace and prosperity in the community and social stability. We could see the role of "harmonious". Harmonious music can make people feel happy. The society would be in harmony and peace. People would be friendly with each other. And "harmony" is the theme of music. Harmonious music can create harmonious society. Harmonious music also would shape harmonious people. Even in the war years, people would have the courage to fight against those who invaded. The historic "Odes and Hymns" was widely circulated in ancient times. It is the main part of ancient culture, which is also the emotional disclosure of the ancients. Benevolence is the purpose of "Odes and Hymns". Therefore, the main theme of "Odes and Hymns" is the praises of the achievements, which reflect the social ethics and people's morality. The music of "Odes and Hymns" is also the true feelings of people. That is the harmony. Music from the heart is the joy of harmony. And we can shape this music with the love. Also, this music could touch the people. The sound of music is perceived by the objects. And we could recognize the music. Finally, the music would convey the emotion. There are many things in the world, such as the affection of parents and children, the love between lovers, the true feelings among friends, the patriotic feelings among the people and so on. All of them are expressed through the music of "Odes and Hymns". These feelings are also sincere expression of the music of "Odes and Hymns". This is a chapter of the music, and a masterpiece of music, which is also the source of ideological and political education. This kind of music inspires people's patriotism, serves the people's passion, and contributes to the realization of social stability and social progress. The music of "Odes and Hymns" represents the improvement of the character and social morality. Music is the manifestation of 
human virtue. People can express their sincere feelings while speaking with others. Also, people would show their true feelings when doing things. However, music can express its own feelings through expressions. Music also represents the voice of the country and people's wishes. Thus, music can be close to the hearts of ordinary people. In the content and the language, music can reveal the true feelings and the feelings of musicians. We could create the good music with the benevolence and the kindness. The music of "Odes and Hymns" came from the gentleman's work. And the musicians have strong capability in communication. Also, they have noble morality. In contrast, the listeners are psychologically noble.

At present, some scholars have put forward that the colleges and universities should provide music education of "Odes and Hymns" for the undergraduates. And they should introduce the elegant music to educate the college students to carry on the humanistic accomplishment. However, colleges and universities need to choose music. Just as Mencius's demands of the music, the music must be positive and energetic. The colleges and universities couldn't choose decadent, negative, desperate and extravagant music or even anti-ethical music.

\section{CONCLUSION}

In short, the educational goal of Confucianism is to realize the people's all-round education, to realize the love between people, and to cultivate the capable and virtuous gentlemen who aim at carrying forward and practicing their benevolence. It is also the requirement of talented people in today's society. No matter Mencius's theory of "doctrine of good human nature" or Xunzi's theory of "doctrine of evil human nature", it is actually compatible. The two theories advocate the principle of "to stop evil and be good". They pursue the identity, and attach importance to acquired environment. They have a great impact on good humanistic education. All of these theories advocate the principle of "being good" through education, self-cultivation and other means.

Universities would bear the unshirkable responsibility. That is to say, the colleges and universities should cultivate college students with both ability and political integrity. The cultivation and improvement of the humanistic quality of college students determines the success of higher education. Colleges and universities should excavate Confucianism's music education ideology deeply, take its essence and abandon its dross. The colleges and universities should strengthen and improve the humanities education of college students. And then, it would exert a far-reaching influence on the development of educational thoughts in the future. Also, it would have a great significance to the establishment of a harmonious social order. The college students would establish a correct outlook on life, worldview and values.

\section{REFERENCES}

[1] [USA] Bennett Raymer. Xiong Lei translation. Music education philosophy [M]. People's Music Publishing House 2005.
[2] Qi Haiwen. Confucianism music education [M]. Zhengzhou, Henan province: Henan People's Publishing House, 2004: 215

[3] Yu Dongxin, Liu Haixia. The thought of Confucian music education [J]. Journal of Inner Mongolia university, 2000, (05).

[4] Li Meiyan. Ancient Chinese music education thought [M]. Taipei: Taipei Liwen Cultural Publishing House, 2004: 50.

[5] Gao Wei, Wang Junjie. Analysis on the significance of Confucian music education $[\mathrm{J}]$. Journal of Hebei University (Philosophy and Social Science), 2010,35 (01): 128-132. [2017-08-13] .

[6] Yin Hongyun. On Confucian music education and its contemporary significance [D]. Qufu Normal University, 2015.

[7] Xing Lifang. Confucianism and its effectiveness [D]. Nankai University, 2014. 